\title{
CONSUMERS' SATISFACTION, TRUST, AND LOYALTY TOWARD THE HIJAB ONLINE SHOPS
}

\author{
Arief Hendarto*)1, Hari Wijayanto**), and Istiqlaliyah Muflikhati***) \\ *) School of Business, IPB University \\ Jl. Raya Pajajaran, Bogor 16151, Indonesia \\ ${ }^{* *}$ Department of Statistic, Faculty of Mathematics and Natural Sciences, IPB University \\ Jl. Meranti Wing 22 Level 4, Dramaga, Bogor, Indonesia 16680 \\ ${ }^{* * *}$ Department of Family and Consumer Sciences, Faculty of Human Ecology, IPB University \\ Jl. Lingkar Akademik, Dramaga, Bogor, Indonesia 16680
}

\begin{abstract}
The number of hijab users in Indonesia is increasing. This study aims to analyze online hijab shop customers' characteristics, the level of satisfaction, trustworthiness, consumer loyalty, and the influence between the level of satisfaction and trust on consumers' loyalty to who buy the hijab at online stores in Indonesia. Data were collected through a questionnaire with a Likert Sala, made using Google Form and distributed online. The study sample of 153 people was determined using a purposive sampling technique. The collected data were analyzed using Structural Equation Modeling (SEM) - Partial Least Square (PLS). The results of this study indicate that: (1) online hijab shop customers are dominated by students aged 17-25 years; (2) Consumer Satisfaction Index (CSI) of 79\%, which means that consumers are satisfied with the e-commerce services used by consumers; (3) online hijab shop customers are satisfied with the services provided by online hijab shops; (4) the level of customer loyalty is $72 \%$, which means that consumers have high enough loyalty so that they are willing to keep shopping at the current online hijab shop and are willing to recommend it to consumers' colleagues or relatives; and (5) customer satisfaction and trust have a significant effect on customer loyalty. From the results of this study, it is recommended that online hijab shop managers provide hijab that suits students and students' needs to use them at school or campus and always maintain customer satisfaction and trust so that they continue to be loyal customers.
\end{abstract}

Keywords: hijab online, IPA, satisfaction index, trust, loyalty index

\begin{abstract}
Abstrak: Jumlah pengguna hijab di Indonesia semakin meningkat. Penelitian ini bertujuan menganalisis karakteristik pelanggan toko hijab online, tingkat kepuasaan, kepercayaaan, dan loyalitas konsumen, serta pengaruh antara tingkat kepuasaan dan kepercayaan terhadap loyalitas konsumen yang membeli hijab di toko online di Indonesia. Data dikumpulkan melalui kuisioner dengan sala likert yang dibuat menggunakan google form dan disebarkan secara online. Sample penelitian sebanyak 153 orang ditentukan dengan menggunakan purposive sampling technique. Data yang terkumpul dianalisis menggunakan Structural Equation Modeling (SEM) - Partial Least Square (PLS). Hasil penelitian ini menunjukkan bahwa: (1) pelanggan toko hijab online didominasi oleh siswa dan mahasiswa yang berusia 17-25 tahun; (2) Indeks Kepuasan Konsumen (CSI) sebesar 79\% yang berarti bahwa konsumen puas terhadap pelayanan e-commerce yang digunakan konsumen; (3) pelanggan toko hijab online puas dengan layanan yang diberikan toko hijab online; (4) tingkat loyalitas pelanggan $72 \%$, artinya konsumen mempunyai loyalitas yang cukup tinggi sehingga bersedia untuk tetap berbelanja pada toko hijab online yang digunakan saat ini dan bersedia untuk merekomendasikan kepada rekan atau kerabat konsumen; dan (5) kepuasan dan kepercayaan pelanggan berpengaruh signifikan terhadap loyalitas pelanggan. Dari hasil penelitian tersebut, disarankan bagi pengelola toko hijab online untuk menyediakan hijab yang sesuai kebutuhan siswa dan mahasiswa untuk digunakan ke sekolah atau ke kampus dan senantiasa menjaga kepuasan dan kepercayaan pelanggan sehingga mereka terus menjadi pelanggan setia.
\end{abstract}

Kata kunci: hijab online, IPA,index kepuasan, kepercayaan, index loyalitas

${ }^{1}$ Corresponding author:

Email: a.hendarto34@gmail.com 


\section{INTRODUCTION}

In recent years, the number of Muslim women wearing the hijab in Indonesia has continued to increase. Based on research conducted by Utomo et al. (2018), by taking a sample of 1443 Muslim women in Jakarta, it was found that $26 \%$ of the sample studied wore hijab. They also said that the situation was different from thirty years ago when the number of Muslim women in Indonesia who wore the hijab was far less. Research conducted by Wagner et al. (2012) found that most women in Indonesia have seen the use of the hijab not only as a religious obligation but for reasons of comfort and to look more fashionable because currently wearing the hijab has become a trend. among Indonesian women. In fact, the use of the hijab has now become a lifestyle and a trend of wearing hijab among young women in Indonesia known as Hijabers (Beta, 2014; Kartajaya et al. 2019). The increasing trend in using the hijab is also supported by fashion styles and motivation to follow fashion developments (Hassan and Harun, 2016).

The increasing trend of wearing the hijab has created business opportunities for Muslim clothing manufacturers and Muslim clothing traders (Dewia and Bambang Syairudin, 2015). The hijab design has now developed and adapted to modern clothing development (Nistor, 2017). The increasing demand for hijab is being taken advantage of by many online shops, which make hijab readily available through online stores. Meanwhile, in managing an online store, information that can help sales is very important. Some of this information includes consumer characteristics, level of satisfaction, and loyalty. Buyer characteristics have a role in determining whether the buyer will buy a certain product (Rehman et al. 2017). However, these characteristics' effect will be different for each product (Keisidou et al. 2011). For this reason, information about specific customer characteristics for the product being sold is crucial. Satisfaction has also been shown to affect product re-purchases. This means that the higher the level of customer satisfaction, the higher the possibility of the customer to make repeat purchases (Ahn et al. 2004; Okolo, 2017). Likewise, customer loyalty has also been proven empirically to significantly influence sales and company development (Tomic et al. 2018; Bha et al. 2018).

Seeing the importance of the three information presented in the previous research, this study aims to determine the characteristics of consumers and consumer behavior, the level of satisfaction, trust, and consumer loyalty, as well as the influence between the level of satisfaction and trust on the loyalty of consumers who buy hijab in online stores in Indonesia. Previously, several researchers in Indonesia had conducted studies on the characteristics of online shop customers (Zakiatuzzahrah et al. 2018; Yulita et al. 2019). Likewise, customer satisfaction, trust, and loyalty to online stores in Indonesia (Dhiranty et al. 2017; Tirtayani and Sukaatmadja, 2018; Mariana et al. 2018). However, none of these studies has specifically examined customers who buy hijabs in online stores. Therefore, this study provides an update in discussing customers or consumers who buy hijab in online stores.

The approach used in this research is a quantitative approach that is supported qualitatively through literature studies. The method is by distributing questionnaires to informants who are hijab users who are included in the research criteria. These criteria are women living in Jabodetabek who have purchased a hijab at an online shop at least twice in the past year.

Seeing the development of hijab users and the increasing demand for hijab, this research is essential to do to identify consumer characteristics and consumer behavior, levels of satisfaction, trust, and consumer loyalty to online shop managers that provide hijab and analyzing the influence between levels of satisfaction and trust on consumer loyalty hijab online. By utilizing this information, it is hoped that online shop managers who sell hijab will be able to prepare better strategies to increase managed online stores' sales and performance.

\section{METHODS}

This research was conducted in Jabodetabek. The location selection was made because Jabodetabek is the second-largest megapolitan city with a population of around 32 million and the convenience and suitability of the research object. This research activity was carried out from June to August 2018.

The type of data from this research is quantitative data. The data source is women who come from the Greater Jakarta area. In addition, they have also purchased hijab in online stores at least twice in the past year. 
The data in this study were collected through a questionnaire. The questionnaire is used to collect data on consumer characteristics and consumer behavior, level of satisfaction, trustworthiness, and consumer loyalty. The questionnaire used was made using google form and circulated online to respondents. The questionnaire consists of 29 statements and uses a Likert scale. Thus, the data generated from distributing this questionnaire is in the form of quantitative data.To determine the sample, the researcher used a purposive sampling technique. According to the number of items in question in the questionnaire, namely 29 items, this study's sample size is at least 145 people. There were 200 respondents who filled out the questionnaires from the results of distributing questionnaires, but only 153 respondents met the criteria. Thus, the sample of this study amounted to 153 people.

Data processing and analysis techniques in this study are: Customer Satisfaction Index (CSI) is used to determine the overall level of customer satisfaction with an approach that considers the importance level of the attributes that have been determined so that it can assist in the process of improving performance internally; Customer Loyalty Index (CLI) is used to measure the level of consumer loyalty to online hijab business actors; The Kruskal Wallis test is a ranking-based nonparametric test whose objective is to determine whether there is a statistically significant difference between the level of customer satisfaction and characteristics based on age, marital status, occupation, and education level; Importance and Performance Analysis (IPA) is used to analyze the level of expectations or interests of consumers towards consumer attributes between consumers and online hijab business actors; Partial Least Square (PLS) is a component-based type of SEM with formative construct properties. The external model or evaluation of the measurement model is carried out to assess the model's validity and reliability, as can be seen in Table 1.

Nowadays, more and more women are choosing to wear the hijab. This is a prospect in itself for online shops as more and more people choose to shop for hijab online instead of going directly to the store. With the increasing spread of online hijab shops, it can be found that there is a hypothesis that there is a relationship between consumer characteristics and consumer behavior, their level of satisfaction, trust, and loyalty as well as the influence between the level of satisfaction and trust on consumer loyalty who buys hijab at online stores in Indonesia. The variables in this study can be seen in Table 2.

This study aims to see the effect of online hijab consumer satisfaction, trust, and loyalty, which can be seen in Figure 1. The characteristics of online consumers influence consumer decisions when purchasing hijab online. Not only that, but the quality dimension of online hijab can also affect consumer satisfaction and level of trust. Consumers who are satisfied when making a hijab purchase tend to trust an online shop so that the level of consumer confidence increases. Satisfaction and high consumer confidence can increase consumer loyalty.

Table 1. Summary of Measurement

\begin{tabular}{lll}
\hline Test & Parameter & Rule of Thumb \\
\hline Convergent & Loading Factor & $>0.7$ \\
Validity & Average Variance Extracted (AVE) & $>0.6$ \\
& Communality & $>0.6$ \\
Discriminant & Cross Loading & $>0.7$ \\
Validity & AVE Roots and Correlations among Latent & AVE Root $>$ Correlation between Latent \\
& Constructs & Components \\
Reliability & Cronbach's Alpha & $>0.6$ \\
& Composite Reliability & $>0.6$ \\
\hline Source: & &
\end{tabular}

Source: Hartono and Abdillah (2014) 
Table 2. The variables studied and their indicators

\begin{tabular}{|c|c|c|}
\hline Variables & Indicator & Symbol \\
\hline \multicolumn{3}{|l|}{ Exogenous } \\
\hline \multirow[t]{3}{*}{ Assurance } & Consumers feel safe about electronic payment systems when purchasing hijab online & AS1 \\
\hline & Consumers trust the purchase of hijab online & AS2 \\
\hline & Consumers feel safe when providing personal information when purchasing hijab online & AS3 \\
\hline \multirow[t]{4}{*}{ Ease to Use } & Easy to access online hijab shop & EU1 \\
\hline & The online hijab shop is friendly to use & EU2 \\
\hline & Instructions when purchasing online make it easy & EU3 \\
\hline & Easy to find online hijab shop & EU4 \\
\hline \multirow[t]{3}{*}{ E-Scape } & Information when purchasing hijab online is displayed attractively and informatively & ES1 \\
\hline & The appearance and arrangement of hijab products on an attractive online shop & ES2 \\
\hline & Consumers are satisfied with the design/appearance when purchasing hijab online & ES3 \\
\hline \multirow[t]{3}{*}{ Responsiveness } & It is easy to contact the contact person when buying hijab online & RE1 \\
\hline & Online hijab shops are willing to accept input & RE2 \\
\hline & Online hijab shops are rapidly responding to consumer demand. & RE3 \\
\hline \multirow[t]{3}{*}{ Customization } & Consumers feel that my personal needs are being met when making hijab purchases online. & CU1 \\
\hline & The online hijab shop provides me with information and products by choice & CU2 \\
\hline & Consumers feel they have the same norms and values as I have when purchasing hijab online & CU3 \\
\hline \multicolumn{3}{|l|}{ Endogenous } \\
\hline \multirow[t]{4}{*}{ (satisfaction) } & Consumers are generally satisfied with the service of this online shop & ECS1 \\
\hline & This online shop is fun. & $\mathrm{ECS} 2$ \\
\hline & Consumers are very satisfied with the service of this online shop. & ECS3 \\
\hline & Consumers are very happy with this online shop & ECS4 \\
\hline \multirow[t]{5}{*}{ (trust) } & Consumers are willing to provide personal information to online shops. & ET1 \\
\hline & Consumers will provide credit card numbers to online shops & ET2 \\
\hline & I have no problem paying more for products than the internet & ET3 \\
\hline & Online shops are professional & ET4 \\
\hline & Online shops are trying to fulfill their promise & ET5 \\
\hline \multirow[t]{4}{*}{ (loyalty) } & Consumers will continue to use this online shop & ECL1 \\
\hline & Consumers are willing to pay more at this online shop & ECL2 \\
\hline & Consumers will be willing not to switch to other online stores & ECL3 \\
\hline & Consumers will recommend this online shop to others & ECL4 \\
\hline
\end{tabular}

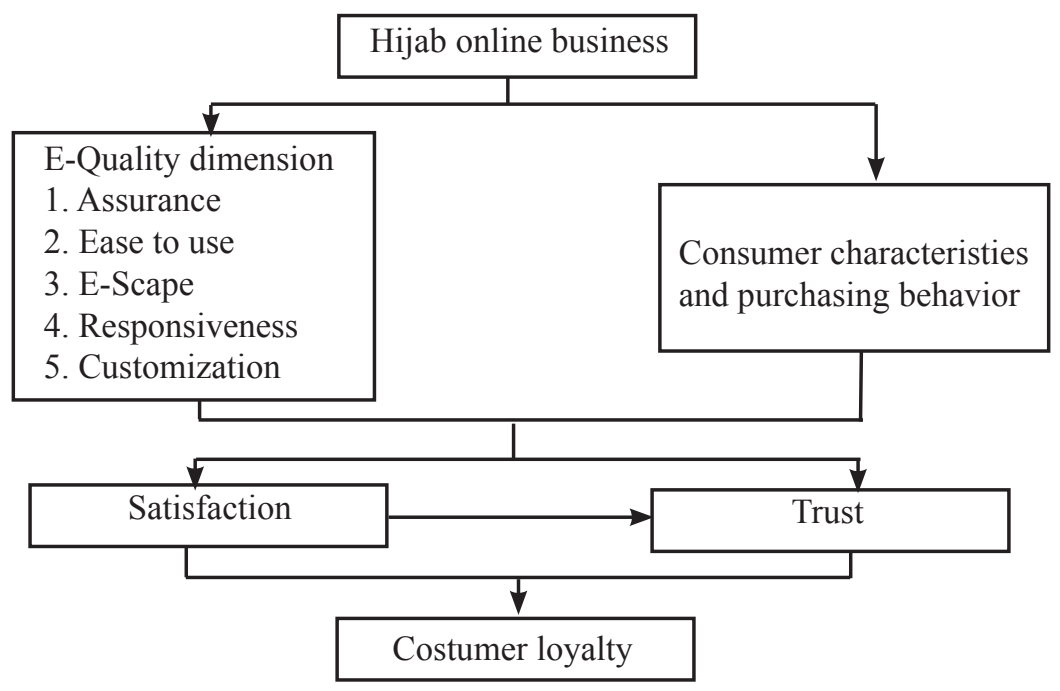

Figure 1. Research framework 


\section{RESULTS}

\section{Consumer Characteristics}

The demographic characteristics of consumers studied in this study are age, marital status, education level, occupation, and residence. As shown in Table 3 below, $82.35 \%$ were consumers aged 17-25 years from the age characteristics. Of the marital status, the unmarried group has a very big interest in shopping at online hijab stores compared to the married group, which is as much as $86.27 \%$. From education, most online hijab shops are dominated by high school and undergraduate education groups as much as $28.10 \%$. From the work of consumers interested in shopping for online hijab stores, the largest is in the non-working group, namely students or students as much as $73.20 \%$. From residential domiciles, which are based on five residential areas, the majority of online hijab shop consumers are dominated by consumers who live in the Jakarta and Bekasi areas.

\section{Hijab Buying Behavior}

In addition to demographic data, this study also obtained some consumer behavior data for online hijab purchases, namely, the purpose of purchasing the hijab, the function of wearing the hijab, the type of hijab purchased, and the total hijab that was purchased. The number of purchases of hijabs of 2-5 pieces was $41.83 \%$ with the aim of the purchase was for own use is $87.58 \%$. The function of wearing the purchased hijab is for daily use is $81.05 \%$, with the dominant type of hijab is a rectangular hijab as much as $56.21 \%$ with the preferred purchase channel on the official website as much as $40.52 \%$.

\section{Consumer Satisfaction Level}

The index level of consumer satisfaction with the online hijab shop in the Greater Jakarta area is analyzed through Assurance, Ease to Use, E-Scape, Responsiveness, and Customization variables. The analysis results show that the Consumer Satisfaction Index (CSI) value is $79 \%$, which means that consumers are satisfied with the e-commerce services used by consumers. The attribute that has the highest value is the appearance and arrangement of hijab products in attractive online stores that are in the E-Scape variable.

\section{Level of Interest and Performance Indicators of Satisfaction}

Importance and Performance Analysis (IPA) as a method that describes the level of importance and performance of each indicator of consumer satisfaction in Figure 2, shows that there are no indicators that are in quadrant $\mathrm{I}$, which is concentrated here, which means that there are no consumer satisfaction indicators for online hijab shops that need attention for improvement. Indicators that are in quadrant II, Easy to access online hijab shops (EU1), friendly online hijab shops (EU2), Instructions when purchasing online makes it easy (EU3), Easy to find online hijab shops (EU4), information at the time of purchase hijab online is displayed attractively and informatively (ES1), appearance and arrangement of hijab products in an attractive online shop (ES2), Consumers are satisfied with the design/appearance when purchasing hijab online (ES3), Easy to contact the contact person when making a purchase hijab online (RE1) and online hijab shops provide me with information and products based on choice (CU2) illustrating that the above indicators are important indicators for consumers who have been fulfilled by hijab e-commerce so that their performance must be maintained.

Indicators that are in quadrant III, Consumers feel safe about electronic payment systems when purchasing hijab online (AS1), Consumers trust purchasing hijab online (AS2), Consumers feel safe when providing personal information when purchasing hijab online (AS3). Online hijab shops are willing to accept input (RE2), online hijab shops respond quickly to consumer requests (RE3), Consumers feel that my personal needs are met when purchasing hijab online (CU1), Consumers feel they have the same norms and values as mine (CU3) indicates that these indicators have low priority or are less important for consumers and e-commerce fulfills them mediocre. Meanwhile, in quadrant IV, there are no indicators in it, meaning that there are no indicators that have a low priority for consumers, but the company has done it excessively.

\section{Consumer Loyalty Level}

The level of the online shop hijab loyalty index measured in this study is divided into four indicators, namely, consumers will continue to use the online shop, consumers are willing to pay more, consumers are willing not to switch to other online stores, and 
recommendations for online shops to others. The overall CLI value of $72 \%$ means that consumers have high enough loyalty so that they are willing to keep shopping at the online hijab shop that is currently used and are willing to recommend to colleagues or relatives of consumers. And of the three purchasing channels, the market place has the largest CLI value, namely $78 \%$, which means that consumers have high enough loyalty so that they are willing to keep shopping at the online hijab shop in the market place and are willing to recommend to colleagues or relatives of consumers.

Table 3. Characteristics of consumer demographics

\begin{tabular}{llcc}
\hline Respondent & characteristics & Total & $(\%)$ \\
\hline Age & $17-25$ & 126 & 82.35 \\
& $26-35$ & 22 & 14.38 \\
& $36-45$ & 4 & 2.61 \\
& $46-55$ & 1 & 0.65 \\
Status & Total Number & 153 & 100 \\
& Not Married & 132 & 86.27 \\
& Married & 21 & 13.73 \\
& Total Number & 153 & 100 \\
& Did not finish high school & 4 & 2.61 \\
& High School & 88 & 57.52 \\
& D3 & 13 & 8.50 \\
& S1 & 43 & 28.10 \\
& S2 & 5 & 3.27 \\
& Total Number & 153 & 100 \\
\hline
\end{tabular}

\section{Analysis of Differences in Customer Satisfaction with Online Hijab Shops Based on the Characteristics of Respondents}

Different tests were carried out to determine whether there were differences in satisfaction with the online hijab shop seen from the respondents' characteristics. Different tests were carried out using the Kruskal Wallis test. A variable is said to have a significant difference if the Asymp value. Sig is less than 0.05 , so from Table 4, it can be seen that there is no significant difference in satisfaction with online hijab shops when viewed from the characteristics of the respondents.

\begin{tabular}{clcc}
\hline Respondent & characteristics & Total & $(\%)$ \\
\hline Profession & Housewives & 8 & 5.23 \\
& Employees & 22 & 14.38 \\
& Entrepreneur & 7 & 4.58 \\
& Civil Servant/Teacher & 4 & 2.61 \\
& Students & 112 & 73.20 \\
& Total Number & 153 & 100 \\
Domicile & Jakarta & 56 & 36.60 \\
& Bogor & 23 & 15.03 \\
& Depok & 14 & 9.15 \\
& Tangerang & 15 & 9.80 \\
& Bekasi & 45 & 29.41 \\
& Total Number & 153 & 100 \\
\hline
\end{tabular}

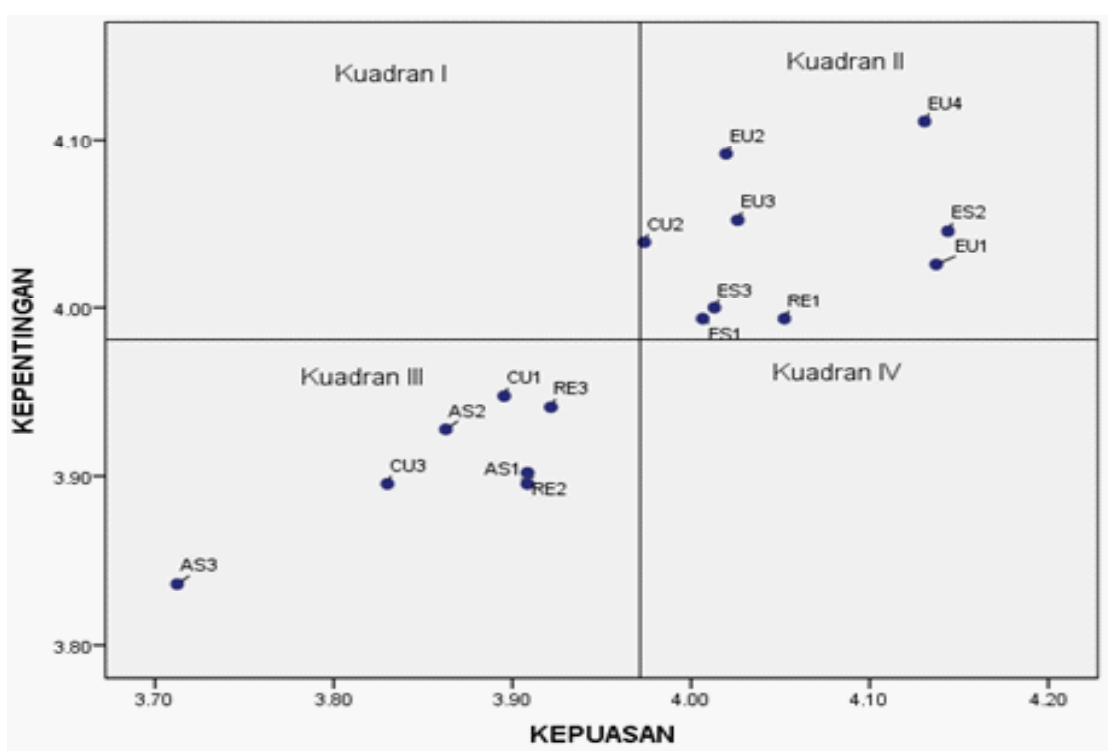

Figure 2. Consumer's Importance and Performance Analysis (IPA) 


\section{Validity and Reliability Test}

Validity test parameters can be determined based on the results of AVE, Communality, and factor loading. An indicator is declared valid if the AVE and Communality values are more than 0.5 and the loading factor value is more than 0.7 . While the parameters used to assess reliability are Cronbach alpha and composite reliability. According to Jogiyanto and Abdillah (2009) based on Chin (1995), an indicator is said to be reliable if the value of Cronbach alpha is more than 0.6 and the composite reliability is more than 0.7 . The validity and reliability tests in the study can be valid and reliable based on Figure 3 and Table 5.

Table 4. Kruskal Wallis test results

\begin{tabular}{llcc}
\hline Characteristic & df & Chi-square & Asymp. Sig \\
\hline Age & 2 & 0.567 & 0.904 \\
Status & 2 & 1.71 & 0.425 \\
Domicile & 5 & 5.01 & 0.286 \\
Education & 4 & 7.737 & 0.102 \\
Profession & 5 & 4.374 & 0.497 \\
\hline
\end{tabular}

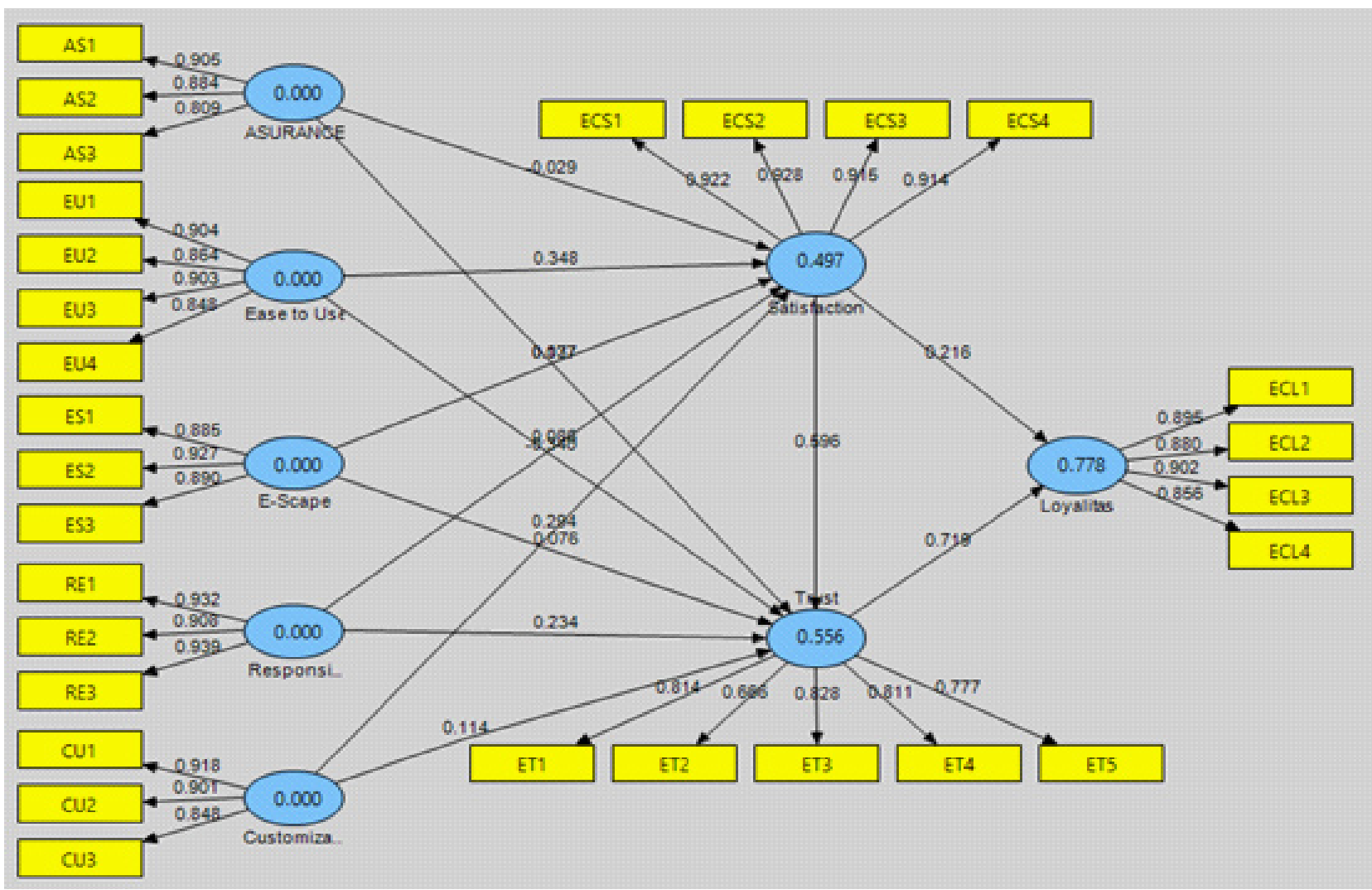

Figure 3. Path diagram with path coefficient values

Table 5. Constructs of reliability and validity

\begin{tabular}{llccc}
\hline Variable & Cronbach's Alpha & Composite Reliability & AVE & Communality \\
\hline Asurance & 0.8335 & 0.9006 & 0.7518 & 0.7518 \\
Customizations & 0.8678 & 0.9190 & 0.7911 & 0.7911 \\
E-Scape & 0.8840 & 0.9282 & 0.8118 & 0.8118 \\
Ease to Use & 0.9029 & 0.9322 & 0.7749 & 0.7749 \\
Loyalitas & 0.9060 & 0.9342 & 0.7803 & 0.7803 \\
Responsiveness & 0.9173 & 0.9478 & 0.8582 & 0.8582 \\
Satisfaction & 0.9392 & 0.9564 & 0.8458 & 0.8458 \\
Trust & 0.8400 & 0.8864 & 0.6107 & 0.6107 \\
\hline
\end{tabular}




\section{Structural Model Evaluation}

This study uses the inner model evaluation in SmartPLS. The parameters used to evaluate the inner model in SmartPLS are the determinant coefficient (R2 test) and the path coefficient or t-value. The value of R2 is used to measure the level of variation in changes in the independent variable. R2 values are shown in Table 6.

Table 6. R-SquareValue

\begin{tabular}{lc}
\hline Variable & R Square \\
\hline Loyalty & 0.7778 \\
Satisfaction & 0.4974 \\
Trust & 0.5557 \\
\hline
\end{tabular}

\section{Hypothesis testing}

The next test is hypothesis testing with path coefficients. Path coefficient is a coefficient that shows the level of significance in hypothesis testing. The hypothesis used in this study is the two-tailed hypothesis (two-tiled). Therefore, the hypothesis is accepted if it has at-statistic value of more than 1.96, as seen in Table 7 .

\section{Analysis of Variables Affecting Satisfaction}

There are five variables in the model that affect customer satisfaction. These variables are assurance, customization, e-scape, ease of use, and responsiveness. However, based on this study's results, there are only two variables that have a significant effect on consumer satisfaction with online hijab shops. The two variables are the customization and easy to use variables. Judging from variable assurance, this study's results are supported by the results of research conducted by Belanger et al. (2002), who also found that assurance problems or variables related to security are not something that customers pay too much attention to when shopping at online stores. Their research results also found that customers are more concerned with features that provide conveniences, such as comfort, appearance, and ease of use. In terms of e-scape, which focuses on the availability of product information and product appearance, the results of this study indicate that e-scape does not have a significant effect on customer satisfaction of online hijab shops. This is because the display and information on the online shop are blocked from being in accordance with the original product (Tharob et al. 2017). Furthermore, in this study, it was found that the responsiveness variable was also not a variable that had a significant effect on customer satisfaction. This finding is different from the results of previous studies which found that responsiveness has a significant effect on online store customer satisfaction (Kusdibyo and Februadi, 2019; Khairunnisa et al. 2018). These different results later need to be investigated further specifically to find out the reasons why online hijab shop customers judge that responsiveness does not have a significant effect on satisfaction.

Customizations are variables found to have a significant effect on customer satisfaction of online hijab shops. Customization is a useful tool for online businesses because the information collected by administrators can be stored and used on subsequent visits. According to the results of research by Wang and Chang (2014), the level of consumer perception on virtual product customization has a positive influence on the level of satisfaction with the product.

In this study, easy to use has the greatest influence on customer satisfaction. This is in line with research by Jun et al. (2004), which found that there was a significant and positive relationship between ease of use and satisfaction conducted in the United States. In research conducted by Zhou (2011) on mobile website users, the results show that the perception of ease of use also significantly affects decision. So that the easier it is to access and get directions from online stores, it will increase customer satisfaction.

\section{Analysis of Variables Affecting Trust}

In this study, six variables were analyzed for their influence on trust, namely assurance, customization, e-scape, ease of use, responsiveness, and satisfaction. The results found that there are three variables that significantly influence consumer confidence, including the variables of ease to use, responsiveness, and satisfaction. In this study, it was found that ease of use had a significant effect on trust but negatively identified that the easier it was for an online store to be visited or used, the lower consumer confidence was. This is in contrast to Wilson's (2019) research, which states that ease to use has a positive relationship to trust in social network services, and Fayad and Paper (2015), which states that it has a direct and significant influence on consumer trust in e-commerce sites. 
Table 7. Result of path coefficient and t-test

\begin{tabular}{|c|c|c|c|c|c|}
\hline Code & Hypothesis & Path coefficient & T Statistics & Significance & Information \\
\hline H1 & $\mathrm{AS} \rightarrow \mathrm{ECS}$ & -0.0292 & 0.2206 & Not significant & Rejected \\
\hline $\mathrm{H} 2$ & $\mathrm{AS} \rightarrow \mathrm{ET}$ & 0.1370 & 1.4677 & Not significant & Rejected \\
\hline H3 & $\mathrm{CU} \rightarrow \mathrm{ECS}$ & 0.2944 & 2.3797 & Significant & Accepted \\
\hline $\mathrm{H} 4$ & $\mathrm{CU} \rightarrow \mathrm{ET}$ & 0.1142 & 0.9830 & Not significant & Rejected \\
\hline H5 & $\mathrm{ES} \rightarrow \mathrm{ECS}$ & 0.0765 & 0.6441 & Not significant & Rejected \\
\hline H6 & $\mathrm{ES} \rightarrow \mathrm{ET}$ & 0.0762 & 0.7465 & Not significant & Rejected \\
\hline H7 & $\mathrm{EU} \rightarrow \mathrm{ECS}$ & 0.3476 & 2.4597 & Significant & Accepted \\
\hline H8 & $\mathrm{EU} \rightarrow \mathrm{ET}$ & -0.3396 & 2.5885 & Significant & Accepted \\
\hline H9 & $\mathrm{RE} \rightarrow \mathrm{ECS}$ & 0.0857 & 0.9125 & Not significant & Rejected \\
\hline H10 & $\mathrm{RE} \rightarrow \mathrm{ET}$ & 0.2342 & 2.2713 & Significant & Accepted \\
\hline H11 & $\mathrm{ECS} \rightarrow \mathrm{ECL}$ & 0.2156 & 3.7994 & Significant & Accepted \\
\hline H12 & $\mathrm{ECS} \rightarrow \mathrm{ET}$ & 0.5965 & 6.6585 & Significant & Accepted \\
\hline $\mathrm{H} 13$ & $\mathrm{ET} \rightarrow \mathrm{ECL}$ & 0.7189 & 13.7563 & Significant & Accepted \\
\hline
\end{tabular}

Information:

H1: There is a significant effect of Assurance on Satisfaction

$\mathrm{H} 2$ : there is a significant effect of assurance on trust

H3: There is a significant effect of Customizations on Satisfaction

H4: There is a significant effect of Customizations on Trusts

H5: There is a significant effect of E-Scape on Satisfaction

H6: there is a significant effect of E-Scape on Trust

H7: There is a significant effect of Ease to Use on Satisfaction

Although the results of this study contradict these studies, however, Hidayah (2018) research also shows that the ease to use variable has a negative influence on purchasing decisions on a marketplace site. So, it can be concluded that ease to use has the opportunity to have a negative influence on trust which then affects purchasing decisions.

From the Responsiveness variable in this study, it was found that responsiveness significantly affected trust. This is supported by Lee (2015) finding that responsiveness is positively related to trust in online business. Also added by Suki's (2012) research shows that responsiveness significantly affects vendor confidence in $\mathrm{m}$-commerce.

In this study also found that the satisfaction variable has a significant effect on trust. These results are supported by several research results which show that satisfaction is one of the factors that can increase customer trust (Doong et al. 2008; Fang et al. 2011; Flavián et al. 2006; Horppu et al. 2008). Specifically Chou et al. (2015) found that e-satisfaction is positively related to e-trust in online clothing purchases.

Meanwhile, three other variables, namely assurance, customization, e-scape, were found to have no
H8: there is a significant effect of Ease to Use on Trust H9: There is a significant effect of Responsiveness on Satisfaction H10: There is a significant effect of Responsiveness on Trust H11: There is a significant effect of Satisfaction on Loyalty H12: There is a significant effect of Satisfaction on Trust H13: There is a significant effect of Trust on Loyalty

significant effect on customer confidence in the online hijab shop. When viewed from variable assurance, the results of this study contradict the results of previous studies. Several previous researchers have proven that assurance has a significant effect on trust (Bahmanziari et al. 2009; Eid, 2011). Likewise with the e-scape variable, where several studies have found that the appearance of an online store will affect customer trust (Ou and Sia, 2010; Rita et al.2019).

\section{Analysis of Variables Affecting Loyalty}

In this study, researchers analyzed the influence of the satisfaction and trust variables on loyalty. The results showed that the variable satisfaction and consumer confidence and both of them had a significant effect. Lee and Wong (2016) and Brilliant and Achyar (2013) explain that there is a positive and real relationship between satisfaction and loyalty. Chou, Chi-Wen, and Lin (2015) also found their research results that satisfaction is positively related to loyalty in online clothing shopping. The results of Chaudhuri and Holbrook's (2001) research show that loyalty contributes to a continuous process and maintains the valuable and important relationships that trust has created. So it could increase consumer confidence in an online store will increase consumer loyalty. Cyr (2008) also found 
trust in online stores to be strongly associated with Germany and China's loyalty.

\section{Managerial Implications}

This study's results are expected to provide benefits to online hijab shops to improve the quality of service for online hijab sales. The reason is, the hijab industry is now a fashion that is experiencing a positive trend. Given that the Jabodetabek area is a potential area for hijab online shop owners. So that online shops should be able to improve the quality of products and services in order to bring great profits.

In running an online hijab shop business, there are several variables that the manager must pay attention to in order to increase customer satisfaction and loyalty. To increase customer satisfaction, what must be considered is ease of use, customization. Managers must ensure that the online store is easy to find, the system is easy to use, and that there are instructions that are easy to understand. In addition, the product provided must be able to make customers feel that the product is in accordance with their needs. Meanwhile, to increase customer loyalty, managers must always ensure that the system is easy to use, always respond to customer requests or questions quickly and friendly, and ensure that they are satisfied with the services provided. Furthermore, to make customers become loyal customers, managers must always ensure that every customer trusts and is satisfied with their services.

\section{CONCLUSIONS AND RECOMMENDATIONS}

\section{Conclusions}

From the presentation of the research results that have been previously submitted, it can be concluded that in general, online hijab consumers are 17-25 years old with unmarried status. Consumers of online hijab shops are students with high school education levels and domiciled in Jakarta and Bekasi. The average number of hijab purchases is 2-5 pieces of hijab for the purpose of purchasing for daily use. The most popular type of hijab is the rectangular hijab with a purchase channel on the official website. The level of satisfaction and loyalty of online hijab consumers in the Jabodetabek area each has a value above $70 \%$, which means that consumers are satisfied with the performance of online hijab shop services and are loyal. Consumer satisfaction and trust have a significant effect on consumer loyalty in purchasing hijabs in online stores.

\section{Recommendations}

Considering the results of this study, online hijab shop entrepreneurs are advised to provide hijabs that are suitable for customers aged 17-25 years, especially for daily use at school or on campus. This is because the customers who buy the most hijabs from online stores are students and university students. Furthermore, entrepreneurs must ensure that their online shop is easy to find and easy for customers to use, from the process of choosing a hijab to the payment process. In addition, entrepreneurs must also ensure that every customer gets fast and friendly service. So, all customers will feel satisfied and become loyal customers of the online hijab shop they have.

Seeing some of the research results that are different from previous studies, further research that analyzes the reasons that make the results of this study different from previous studies needs to be carried out. In addition, further research is also suggested to add other quality dimensions that have not been studied in this study, such as the dimensions of security and consumer privacy which can affect consumer trust so that it is expected to expand the analysis of satisfaction and trust in loyalty to consumers who make purchases online. It is also hoped that further research can see the effect of these three variables on each of the online purchasing channels, namely, the official website, market place, and social media.

\section{REFERENCES}

Ahn T, Ryu, S, and Han I. 2004. The impact of the online and offline features on the user acceptance of Internet shopping malls. Electronic Commerce Research and Applications 3(4):405-420.

Bahmanziari T, Odom MD, Ugrin JC. 2009. An experimental evaluation of the effects of internal and external e-Assurance on initial trust formation in $\mathrm{B} 2 \mathrm{C}$ e-commerce. International Journal of Accounting Information Systems 10(3):152-170.

Belanger F, Hiller JS, Smith WJ. 2002. Trustworthiness in electronic commerce: the role of privacy, security, and site attributes. The Journal of Strategic Information Systems 11(3-4): 245270. 
Beta AR. 2014. Hijabers: How young urban muslim women redefine themselves in Indonesia. The International Communication Gazette 76(45):377-389.

Bhat SA, Darzi MA, Parrey SH. 2018. Antecedents of customer loyalty in banking sector: a mediational study. Vikalpa: The Journal for Decision Makers 43(2):92-105.

Brilliant MA, Achyar A. 2013. The impact of satisfaction and trust on loyalty of e-commerce customers. Asean Marketing Journal 5(1):5158.

Chaudhuri A, Holbrook MB. 2001. The chain of effect from brand trust and brand effect to brand preformance: the role of brand loyalty. Journal of Market Focused Management 65:81-93.

Chou S, Chi-Wen C, Lin JY. 2015. Female online shoppers. Internet Research 25:542-561.

Cyr D. 2008. Modeling web site design across cultures: relationships to trust, satisfaction, and e-loyalty. Journal of Management Information Systems 24:47-72.

Dhiranty A, Suharjo B, Suprayitno G. 2017. An analysis on customer satisfaction, trust and loyalty toward online shop (A case study of tokopedia.com). Indonesian Journal of Business and Entrepreneurship 3(2):101-110.

Doong HS, Wang HC, Shih HC. 2008. Exploring loyalty intention in the electronic marketplace. Electronic Markets 18:142-149.

Eid M I. 2011. Determinants of e-commerce customer satisfaction, trust, and loyalty in Saudi Arabia. Journal of Electronic Commerce Research 12(1):78-93.

Fang YH, Chiu CM, Wang T G. 2011. Understanding customers'satisfaction and repurchase intentions: an integration of IS success model, trust, and justice. Internet Research 21:479-503.

Fayad R, Paper D. 2015. The technology acceptance model e-commerce extension: A conceptual framework. Procedia Economics and Finance 26:1000-1006.

Flavián C, Guinalíuand M, Gurrea R. 2006. The role played by perceived usability, satisfaction and consumer trust on website loyalty. Information and Management 43:1-14.

Gerson RF. 2001. Mengukur Kepuasan Konsumen. Jakarta: PPM.

Griffin J. 1995. Customer Loyalty, How to Earn it and How to Keep It. San Francisco: Jossey-Bass Publishers.
Hassan SH, Harun H. 2016. Factors influencing fashionconsciousness in hijab fashionconsumption among hijabistas. Journal of Islamic Marketing 7(4):476-494.

Horppu M, Kuivalainen O, Tarkiainen A, Ellonen HK. 2008. Online satisfaction, trust and loyalty, and the impact of the offline parent brand. Journal of Product and Brand Management 17:403-413.

Jun M, Yang Z, Kim D. 2004. Customers' perceptions of online retailing service quality and their satisfaction. International Journal of Quality and Reliability Management 21:817-840.

Kantsperger R, Kunz WH. 2010. Consumer trust in service companies: a multiple mediating analysis. Managing Service Quality 20(1):4-25.

Kartajaya $\mathrm{H}$ et al. 2019. Segmenting Islamic fashion lifestyle on Indonesian woman. Research Journal of Textile and Apparel 23(4):306-322.

Keisidou E, Sarigiannidis L, Maditinos D. 2011. Consumer characteristics and their effect on accepting online shopping, in the context of different product types. International Journal of Business Science and Applied Management $6(2): 31-51$

Khairunnisa N, Munandar JM, Najib M. 2018. Customer Satisfaction and Loyalty on Customer Delivered Value of Postal and Shipping Service. International Journal of Research and Review 5(11):15-27.

Kotler P, Armstrong G. 2003. Dasar-Dasar Pemasaran. Jakarta: Gramedia.

Kusdibyo L, Februadi A. 2019. The effect of electronic service quality on customers satisfaction and loyalty in online shopping. IOP Conf. Series: Materials Science and Engineering 662:1-8.

Lee WO, Wong LS. 2016. Determinants of mobile commerce customer loyalty in Malaysia. Procedia - Social and Behavioral Sciences 224:60-67.

Mariana VE et al. 2018. Customer trust of online shopping using social media. IOP Conf. Series: Materials Science and Engineering 403:1-5.

Milne GR, Rohm AJ. 2000. Consumer privacy and name removl across direct mareting channels: exploring pot-in and opt-out alternative. Journal of Publice Policy and Marketing 19(2):238-249.

Mowen JC, Minor M. 2002. Perilaku Konsumen Ed. ke-5. Jakarta: Erlangga.

Okolo VO. 2017. Evaluation of the Effects of Marketing Strategies on Consumer Patronage of Restaurants in Enugu (A Study of Mr. Bigg's). European 
Journal of Social Sciences 55(3):297-320.

Ou CX, Sia CL. 2010. Consumer trust and distrust: An issue of website design. International Journal of Human-Computer Studies 68(12):913-934.

Rehman FU etal.2017. Determinants of personal factors ininfluencing the buying behavior ofconsumers in sales promotion: a caseof fashion industry. Young Consumers 18(4):408-424.

Reibstein DJ. 2002. What attracts customer to online stores and what keeps them coming back? Journal of the Academy of Marketing Science 30(4):456-473.

Rita P, Oliveira T, Farisa A. 2019. The impact of e-service quality and customer satisfaction on customer behavior in online shopping. Heliyon 5(10): 02690.

Rust RT, Kannan PK. 2002. The era of e-service: New directions in theory and practice. New York: M.E. Sharpe .

Sangadji EM, Sopiah. 2013. Prilaku Konsumen: Pendekatan Praktis. Disertai Himpunan Jurnal Penelitian. Yogyakarta: Penerbit Andi.

Sarwono J, Prihartono K. 2012. Perdaganan Online: Cara Bisnis di Internet. Jakarta: Penerbit Elex Media Komputindo.

Srinivasan SS, Anderson R, Ponnavolu K. 2002. Customer loyalty in e-commerce: An exploration of its antecedents and conequences. Journal of Retailling 78(1):41-51.

Sumarwan U. 2015. Perilaku Konsumen: Teori dan Penerapan dalam Pemasaran. Jakarta: Ghalia.

Tharob GF, Mingkid E, Paputungan R. 2017. Analisis hambatan bisnis online bagi mahasiswa Unsrat. Acta Diurna 6(2):1-19.

Tirtayani IG, Sukaatmadja IP. 2018. The effect of perceived website quality, e-satisfaction, and e -trust towards online repurchase intention. International Journal of Economics, Commerce and Management 6(10):262-287.

Tomic I et al. 2018. An empirical study of employee loyalty, service quality, cost reduction and company performance. Economic ResearchEkonomska Istraživanja 31(1):827-846.

Turban E et al. 2010. Electronic Commerce: A Managerial Perspective. New Jersey: Pearson Prentice Hall, Inc.
Utomo A et al. 2018. Who wears the hijab? Predictors of veiling in greater jakarta. Review of Religious Research 60:477-501.

Venkatesh V. 2000. Determinants of perceived ease of use: integrating control,intrinsic motivation, and emotion into the technology acceptance model. Information System 11(4):342-365.

Wagner W et al. 2012. The veil and Muslim women's identity: Cultural pressures and resistance to stereotyping. Culture and Psychology 18(4):521541.

Wang W, Chang W. 2014. A study of virtual product consumption from the expectancy disconfirmation and symbolic consumption perspectives. Information Systems Frontiers 16:887-908.

Wilson N. 2019. The impact ofperceived usefulness andperceived ease-of-use toward repurchase intention in the Indonesian e-commerce industry. Jurnal Manajemen Indonesia 19(3):241-249.

Xue M, Harker P. 2002. Customer efficiency: concept and its impact on e-business management. Journal of service Research 4(4):253-267.

Yousafzai SY, Pallister J, Foxall GR. 2003. A proposed model of e-trust for electronic banking. Technovation 23:847-860.

Yulita FH, Simanjuntak M, Sartono B. 2019. Shopping behavior of indonesian customer in modern retail. Russian Journal of Agricultural and Socio-Economic Sciences 4(88):95-101.

Zakiatuzzahrah et al. 2018. Impulsive and compulsive buying in retail business: An overviewof consumer behavior in indonesia. Russian Journal of Agricultural and Socio-Economic Sciences 7(79):107-112.

Zeithaml V, Parasuraman A, Malhotra A. 2005. A conceptual framework for understanding e-service quality: implications for future research and managerial practice. Journal of Service Research 7(10):1-21.

Zhou T. 2011. Examining the critical success factors of mobile website adoption. Online Information Review 35:636-652. 